\title{
Europe alarmed at US plan for space developments
}

\section{- SDI could break ABM treaty - Space station - a military base?}

\section{Washington \& London}

EUROPEAN governments are increasingly concerned by what they see as the drive by the US military to dominate space through the Strategic Defense Initiative (SDI) as well as by a renewed interest in the space station programme.

Mr George Schulz, the US Secretary of State, has met European delegates during the past week in an attempt to allay their fears over what appears to be a new political momentum behind an early deployment of SDI. And representatives of the European Space Agency (ESA) have been in Washington trying to determine the motives behind the plans being developed by the Department of Defense (DoD) for the space station.

The Belgian foreign minister and present head of the Council of Ministers of the European Communities, Mr Leo Tindemans, claimed that there is extensive unease among European governments about SDI. The Anti-Ballistic Missile (ABM) Treaty, now 15 years old, restricts full deployment, the European governments claim, and they want research on the SDI project to be curtailed to comply. The United States appears not to agree.

But the Europeans are more than surprised at the revived interest in the space station, previously considered an exclusively civil project. The SDI ambitions of the United States and the new plans for the station, many European observers fear, could exert pressure on the North Atlantic Treaty Organization and scupper any hopes of early agreement with the Soviet Union on restricting the use of nuclear weapons. The Soviet Union has consistently tried to arrest the progress of SDI and considers the project to be substantially less advanced than is claimed by the United States.

European participation in the US project to build a space station will depend on a meeting arranged for 11 and 12 February in Washington with all international participants. An ESA delegation will examine several issues raised in a document prepared by NASA after discussion with US government agencies on the future military interests in the space station.

Negotiations planned for last month were delayed at the request of DoD to give it time to review its interest in participating in the multinational project.

The new US bargaining position was worked out late on the evening of 4 February, and transmitted to the countries in- volved. Although no details of the new US position were released, NASA administrator James Fletcher told a House of Representatives committee on Thursday that the space station would still be reserved for peaceful purposes.

In other testimony, Fletcher maintained that the administration's request for $\$ 767$ million for 1988 for the space station would meet the goal of operational capability "in the mid-1990s". But it is certain that the current $\$ 8,000$ million estimated cost for the space station will go up. NASA has completed two separate analyses of space station costs following the completion of the preliminary design and definition phase of the project. The details are being worked out with the White House Office of Management and Budget, but the cost is likely to rise as high as $\$ 13,000$ million, if not higher.

A spokesman for ESA said last week that the purpose of this week's meeting is less to negotiate the US draft than to study the practical consequences of what NASA now proposes should be the role of the US Department of Defense in the design, management and operation of the space station. All the member governments will be represented on the ESA delegation by at least one member. The political implications of the draft document will be decided only when the delegation has returned from the United States. It will then be open to ESA governments to seek changes in the draft plan.

ESA hopes that it will still be possible to agree by spring on the development of its Columbus project as an adjunct to the space station proper. But the timetable has been thrown awry by DoD's unexpected declaration of interest, last December. ESA hopes for an agreement among its members in April, in time for some industrial contracts to be let by midsummer

Although the Columbus project, a manoeuvrable vehicle based on the space station, may appear to be a separate project, it will require a dedicated module integral with the space station as a whole.

European diffidence about DoD's possible involvement in the project centres on the extent to which scientific observations by Columbus and its crews may be restricted by US military requirements and on the unwillingness of some European governments to be seen to be contributing to a US-inspired military project in space.

Joseph Palca \& Bill Johnstone
Embarrassing failure for Soviet launches

\section{London}

During the past few weeks, the Soviet Union has had problems with two of its Kosmos satellites. According to the Kettering monitoring group, K-1813, launched on 13 January, was destroyed after a failure of the rocket motor, and K-1817, launched on 30 January, failed to boost into a stable orbit and re-entered prematurely. In spite of the current policy of glasnost (openness), the Soviet space planners have been very reticent about the two Kosmos failures.

They have reason for reticence. Since the Challenger disaster last year, the Soviet Union has offered the services of its Proton launcher to countries wishing to launch communication, meteorological or experimental satellites on a commercial basis. The proposal has the special backing both of Mr Mikhail Gorbachev, who sees it as a first step to his plans for the 'star peace' based on international research projects which he expounded in India last year, and by Prime Minister Nikolai Ryzhkov, who in an interview with the TASS agency last month stressed the "versatile and reliable" nature of the Proton. In fact,

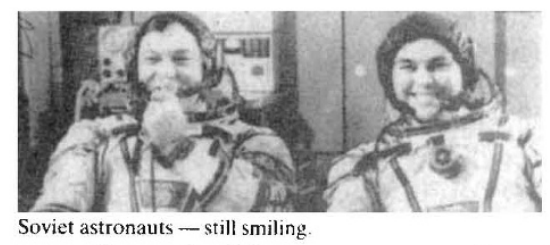

up to the end of last year, according to official Soviet data, there had been seven failures of Proton out of 102 launches, and (in the absence of an official statement) it is impossible to pinpoint the cause of the two recent Kosmos failures.

Even without the commercial launches, however, Soviet cooperation programmes are booming. French and Syrian cosmonauts have been in training for some time, and the Bulgarians have at last been granted a re-run (scheduled in 1988) of their April 1979 mission, which was aborted when the Soyuz transporter failed to link up with Salyut station. Unmanned missions with international cooperation include a study of the surface of Phobos, Xray astronomy, and research into solar activity. One difficulty for western scientists wishing to supply state-of-the-art equipment to joint missions (which could possibly run foul of the CoCom embargo on the export of sensitive technology to the Socialist Bloc) seems to have been partially overcome. In the case of commercial launches, the Soviet side has unequivocally promised that sealed experimental packages would remain sealed, and that there would be no attempt to "pump out technological secrets" from them. The same assurances could surely be extended to joint experimental missions. Vera Rich 